\title{
How Does Climate Change Cause the Extinction of the Ewenki Language and How to Conserve it
}

\author{
Lanxin Chen ${ }^{1, *}$
}

\author{
${ }^{1}$ Beijing Royal School, Beijing, China, 102200 \\ *Corresponding author. Email: chenlanxin@st.brs.edu.cn
}

\begin{abstract}
The Ewenki is one of the minority groups located in Genhe, Inner Mongolia of China. Their mother language is facing a big challenge of extinction today under the unpredictable change of climate. By analyzing the change of climate from 1981-2010 in Genhe forest area and some related qualitative problems, this paper puts forward some suggestions on conserving the Ewenki language.
\end{abstract}

Keywords: climate change, Ewenki language, endangered language, language conservation

\section{INTRODUCTION}

The Ewenki language is the native language of the Ewenki people, the language family belongs to the Altaic language family, the Mantonggus language family, and the Ewenki branch. The language is mainly composed of Sauron, Tungus, and Yakut languages. The three tribal languages are collectively called Ewenki. The Ewenki nationality is an ethnic group with only language and no written language. It is also one of the 28 ethnic groups with a population of less than 300,000 in my country. There are more than 30,000 Ewenki people in the country, of which 10979 are in Ewenki Banner and 8,100 speak Ewenki [1]. Nowadays, the Ewenki language are facing different risks and causing this language to become an endangered language. Climate change is one of the major factor that influence the survival of Ewenki language.

According to the IPCC Fourth Assessment Report pointed out that in the past 100 years, the global climate has been experiencing significant changes characterized by warming [2]. In the past 30 years, climate warming has produced many effects on human society and natural ecosystems on a global scale. And in 2007, China's "Climate Change National Assessment Report" pointed out that the general trend of China's climate change and global warming in the 20th century was basically the same [3]. Most of the area in China has shown this change including Genhe forest area.

\section{METHODOLOGY}

According to the meteorological statistics from 1981 to 2010 of various meteorological stations in Genhe City are selected, including daily average temperature, average humidity, precipitation, sunshine hours, and average wind speed, etc., and perform data processing and climate characteristic analysis on each meteorological element by year [4]. Through linear trend analysis, the characteristics of inter-annual changes are obtained. 


\subsection{Average Annual Temperature}

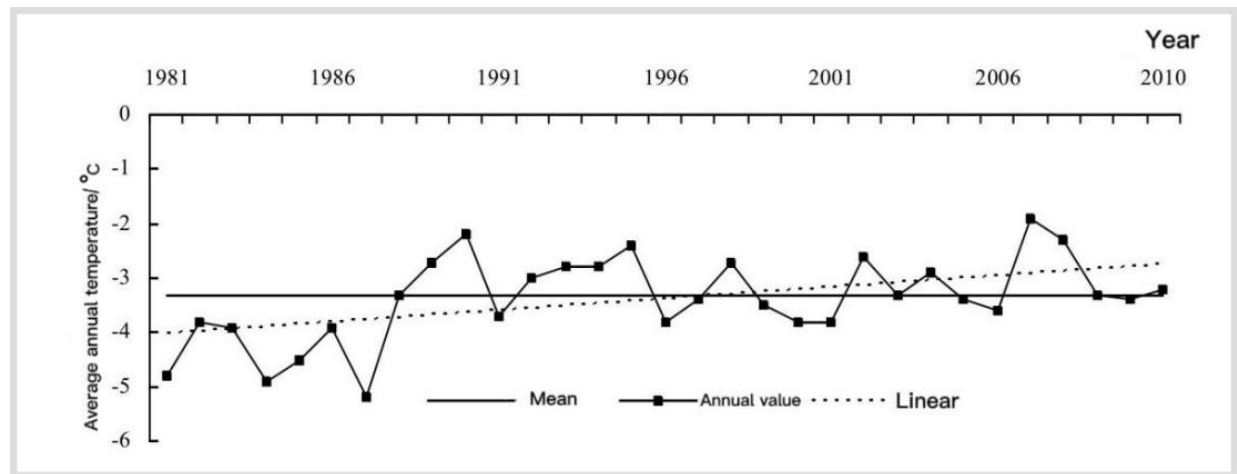

Figure 1 Average Annual Temperature in Genhe from 1981-2010 [5]

From Figure 1, the curve as a whole shows a fluctuating upward trend. The average annual average temperature of Genhe in 1981 to 2010 was $-3.3^{\circ} \mathrm{C}$. The temperature in Genhe forest area was generally low. The average annual temperature anomaly from 1981 to 1990 on the curve was $-0.62^{\circ} \mathrm{C}$, the average annual temperature anomaly from $1991-2000$ was $0.11^{\circ} \mathrm{C}$, and the annual average temperature anomaly from 2001 to 2010 was $0.24^{\circ} \mathrm{C}$, which showed that the curve fluctuated greatly from 1991 to 2000 , and after 1987, the temperature increased greatly, and the increase was greater than the decrease, and the temperature was not higher than the average before 1987.

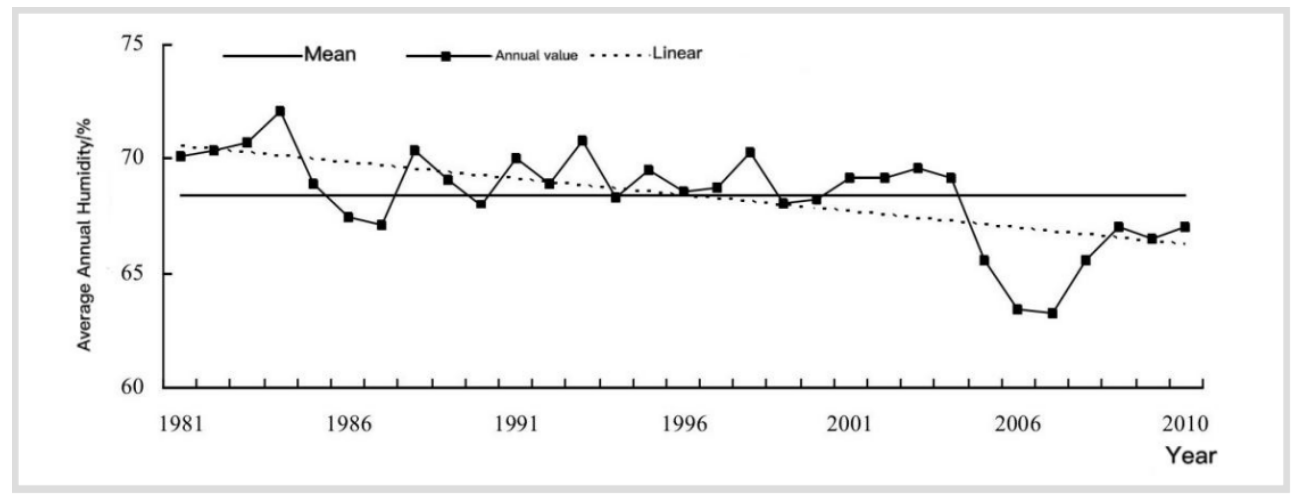

Figure 2 Average Annual Huminity in Genhe from 1981-2010 [5]

\subsection{Average Annual Humidity}

It can be seen from Figure 2 that the curve as a whole shows a downward trend, and the mean annual average humidity between roots and 30 years is $68.4 \%$. The curve fluctuates sharply, with an average annual humidity anomaly value of $1.03 \%$ from 1981 to 1990 , an average annual humidity anomaly of $0.74 \%$ from
1991 to 2000, and an annual average humidity anomaly of -1.53 from 2001 to 2010 . \%, which shows that the curve has not fluctuated much in the first 20 years, only in 1984, 1985, and 1986, the decline was large, and after 2004, the fluctuation was large, and the decline was more obvious.

\subsection{Analysis of Inter Annual Anomalies of Meteorological Elements}

Table 1 Interannual Anomalies of Meteorological Elements in Genhe from 1981-2010 [5]

\begin{tabular}{cccc}
\hline Years\&Anomaly Values & $1981-1990$ & $1991-2000$ & $2001-2010$ \\
\hline Average Temperature & Anomalyl c \\
Precipitation Anomaly/mm & -0.62 & 0.11 & 0.25 \\
Sunlight Anomaly/h & 7.53 & 10.62 & -20.05 \\
$\begin{array}{c}\text { Average Wind Speed } \\
\text { Anomaly/(m/s) } \\
\text { Average Humidity } \\
\text { Anomaly/\% }\end{array}$ & -53.45 & 108.97 & -54.4 \\
$\quad 0.25$ & -0.09 & -0.01 \\
\hline
\end{tabular}


From the analysis in Table 1 , it can be seen that the inter annual temperature anomaly in Genhe Forest Region was negative from 1981 to 1990 , and both were positive from 1991 to 2010 , and the anomalies in the first 10 years were relatively large, indicating that from 1981 to 1990 The annual temperature is relatively low, and then the temperature generally warms up, especially during 1991-2000. The warming range is the most obvious; the interdecadal precipitation anomaly is positive anomaly from 1981 to 2000 , and it is negative anomaly from 2001 to 2010 . Moreover, the negative anomaly value is large, indicating that the precipitation decline from 2001 to 2010 is relatively obvious, but the overall change trend is not obvious; the interdecadal sunshine hours are negative anomalies in 1981-1990 and 2001-2010. The positive anomaly is not obvious; the decadal wind speed is positive anomaly from 1981 to 1990 , and the other years are negative anomalies, and the positive anomaly value is larger from 1981 to 1990 , indicating that the wind speed has a greater trend of change from 1981 to 1990 ; the interdecadal relative humidity was positive anomalies from 1981 to 2000, and negative anomalies in other years, and the negative anomalies were relatively large, indicating that the upward trend from 1981 to 1990 and the downward trend from 2001 to 2010 were both obvious. The above analysis further shows that the changing trend of various meteorological elements is consistent with the linear curve over the years.

\section{IMPACTS BROUGHT BY CLIMATE CHANGE}

Ewenki group are also called the "Reindeer User" because all the reindeer population in China are located in Genhe and the Ewenki use Reindeer as daily vehicle, food, and other source of income; in the other word, the Ewenki rely on reindeer for living. The Ewenki is also the last hunting tribe in China. As the changing of climate including the decreasing of rainfall, reindeers are loosing their main food resource and population. These food resources including different types of ferns, mosses and plants. As the land are getting drier, the amount and distribution of plants are decreasing. One of the plants called "Lurrui" has extinct because of climate change. The loss of Lurrui reveals how important biodiversity to language. After the 10 years of Lurrui's extinction, the word Lurrui is rarely used within the Ewenki population. The new generation even does not understand or know this word. As the old people passing away, the word Lurrui will extinct as Ewenki do not have any written words to record it. Thus, with the loosing of biodiversity, unique words and languages are disappearing at the same time.

Climate change and the decreasing biodiversity has also caused climate migration [6]. Since 2019, the Chinese government has asked the Ewenki to migrate from Genhe forest area to a nearby village Aoluguya. Within that village, Ewenki can still remain their old living style, however they must open the village as tourism purpose in order to have a stable income. According to this policy, the Ewenki has to speak Mandarin and all of their kids are send to local school which all children speak Mandarin in there. This policy act like a double edged sword, in one way, the Ewenki can has a relatively stable income and the reindeers have more abundant food resources, however in another way, it speeds up the extinction of Ewenki language.

\section{THE CONSERVATION OF EWENKI LANGUAGE}

\subsection{Government support}

There are generational differences between modern hunters and traditional hunters. In the face of modern development models and changes in national culture, there are differences in the attitudes of the "modern hunters" who accept modern concepts and the "traditional hunters" who retain traditional values: modern hunters aspire to truly integrate into modern urban life and accept modernization. Lifestyle, more adaptability, they hope to change, but also for the next generation to receive a better education; while traditional hunters are worried, they yearn for unfettered, dependent on nature, accompanied by reindeer Life, the tranquility and peace the deep mountains bring to them is irreplaceable by the hustle and bustle of the town. Although they cannot use words to win the support and recognition of the government, some older hunters still insist on living in the forest. Thus, the government has allowed some of the Ewenki to stay in the forest and keep conserving their old style culture in order to avoid some consequences.

\subsection{Promote the publicity of Ewenki language}

In recent years, with the goal of creating "Aoluguya style and deer cultural characteristics", the local government has developed Aoluguya deer tribe's unique life and production methods and ethnic culture into tourist products, and built settlements under the mountain into a tourism product. A tourist attraction, a museum has been established. The government guide several tribes in hunting spots on the mountain to do tourist reception. The Aoluguya Ewenki compatriots in the residential area under the mountain opened a tourist souvenir shop in their home.

Relying on the Daxinganling Ecological Function Zone in the National Ecological Reserve, with the help of China Cold Extreme Ice and Snow Festival, Aoluguya Deer Cultural Festival and other tourism brands, Aoluguya has increased the popularity and influence of the Deer Ewenki nationality, and the 
cultural value of ethnic minorities has increased. The combination of economic benefits has realized the continuation of the modernization of national culture. Based on unique folk custom resources, unique ecological resources and natural "cold" resources, Genhe City has focused on launching forest ecotourism, folk custom tourism (Aoluguya), ice and snow tourism, fishing tourism and other specialty tourism products, forming a line of tourism. Accommodation, food, travel, shopping, entertainment and other tourist reception facilities. Aoluguya folk culture represented by reindeer culture and birch bark culture is gradually understood and recognized by people. The original ecological tourism with forest folk tour, ice and snow tour and Ewenki orion family tour as the main content is welcomed by tourists. By developing tourism in Aoluguya, people can receive the information in a more direct way thus the awareness of conserve Ewenki culture and language could be raised.

\subsection{Promote maintenance and education of Ewenki culture}

Systematically organize ethnic cultural data and compile ethnography. To improve the compilation of national cultural materials, the joint efforts of relevant departments and all sectors of society are needed. First of all, relevant government departments should play the role of organization and planning, and coordinate the cooperation and responsibilities between various departments; second, it is necessary to solicit opinions from all walks of life in the society, and respect the connotation and cultural form of the Lu Ewenki national culture; third, it is necessary to give play to relevant folk customs. The role of experts and scholars is to ensure the scientificity and accuracy of the compiled content, and invite inheritors and old hunters who are familiar with the national culture to participate in the article, so that the article is more intuitive and national characteristics; finally, it is necessary to insist on detailing the present and omitting the past. Principles to prevent hidden dangers that are detrimental to national unity and social stability.

Give full play to the demonstration effect of cultural inheritors and encourage diversified inheritance models. Relevant departments must carefully review and confirm the qualifications of the inheritors, and grant relevant honorary titles and awards after confirming the qualifications, improve the social status and influence of the inheritors, help the cultural inheritors hold regular national cultural propaganda and skill training, and promote the inheritance of national cultures. At the same time, a subsidy system for cultural inheritance is established to provide cultural inheritors with economic security, so that they can devote themselves to the study of folk culture without any worries. In addition, culture can not only be inherited by people of the same nation, but a diversified model of inheritance is an effective supplementary form for the cultural development of a less populated nation. The population of Shilu Ewenki living in Aoluguya Township is only 243. In order to realize the continuation and development of national culture, the government can organize training courses for national crafts and turn the randomness of cultural inheritance into a systematic one. This is not only a learning platform, it is also a skill to increase profit. At the same time, encourage people from other nationalities who are interested in the $\mathrm{Lu}$ Ewenki national culture to learn folk culture, expand the scope of the main body of inheritance, and realize the continuation and reproduction of national characteristics.

\section{CONCLUSION}

The Ewenki as a minority group in China, their culture has play an important role in Chinese history and cultural diversity. Climate change has brought an irreversible impact to the Ewenki language and their culture, and some policy due to the climate migration may also affect the speed of language extinction. However, based on analyzing the climate characteristics including average temperature; average humidity and some anomaly values over year, it indicates that Ewenki can take the chance to conserve the culture they have right now and create a strong base for their future development.

As the last hunting tribe in China, the adaptation of the Ewenki on the road to modernization has just begun. Whether it is the development of the nation, the change of global environment or the inheritance of culture, it must conform to the regularity of historical development. Those national symbols or characters that have been lost or disappeared need to remain. In the memory of the world, those national cultures that are in trouble or on the verge of extinction need to arouse our attention even more. The author believes that under the leadership of the government, the assistance of all sectors of society, and the unremitting efforts of the Ewenki itself, a path of national cultural development that meets the expectations of the nation and has national characteristics will eventually be opened up to realize the inheritance of national culture, the development of society and the conservation of environment.

\section{AUTHORS' CONTRIBUTIONS}

This paper is independently completed by Lanxin Zhang.

\section{ACKNOWLEDGMENTS}

Thanks to professor André Dhond and Manjiao Song for their assistance in the early stage of this 
review and the background knowledge. Also thanks to Alisa Wang for fixing this review and providing suggestions. Additionally, this work would not have been possible without the work conducted by the people who carried out the primary studies. I acknowledged all the people who helped me in this review as a student of Beijing Royal School.

\section{REFERENCES}

[1] The Ewenki Government the Use of Ewenki Language,

https://www.ewenke.gov.cn/Government/PublicInf oShow.aspx?ID=8072

[2] IPCC Fourth Assessment Report, https://www.ipcc.ch/assessment-report/ar4/

[3] Ding Yihui, Ren Guoyu, Shi Guangyu, Gong Peng, Zheng Xunhua, Zhai Panmao, Zhang Deer, Zhao Zongci, Wang Shaowu, Wang Huijun, Luo Yong, Chen Deliang, Gao Xuejie, Dai Xiaosu. National Assessment Report on Climate Change (I): The History and Future Trends of Climate Change in China [J] Climate change research progress, 2006 (01): 3-8+50.

[4] Yan B. Study on Climatic Characteristics and Changes of Atmospheric Precipitable Amount in Inner Mongolia [D] Lanzhou University, 2013.

[5] Wu Xiaolei. Analysis on the Characteristics of Climate Change in Genhe Forest Area [J] Chinese Agricultural Science Bulletin, 2015, 31(23):210214.

[6] Liang Xuepinf. A Study on the Cultural Dilemma of Ecological Migration - Taking the Aoluguya Envoy Lu Ewenki Nationality as an Example [J] Heilongjiang National Series, 2017(02):31-37. 